\title{
INFLUENCE OF EXOGENOUS APPLICATION OF ABSCISIC ACID ON GAS EXCHANGES IN Hymenaea courbaril L. (FABACEAE) SEEDLINGS SUBJECTED TO WATER DEFICIT
}

\author{
Vanessa de Mauro Barbosa Freitas ${ }^{1 *}$, Silvana de Paula Quintão Scalon ${ }^{2}$, Daiane Mugnol Dresch ${ }^{3}$, Sara da Silva \\ Bastos $^{4}$ e Ana Paula Rissato de Souza ${ }^{5}$ \\ $1^{*}$ Federal University of Grande Dourados, Faculty of Agrarian Sciences, Graduate program of Agronomy and Plant Production, Dourados, \\ Mato Grosso do Sul, Brazil - vanessamauro@yahoo.com.br \\ ${ }^{2}$ Federal University of Grande Dourados, Professor of the Faculty of Agrarian Sciences, Dourados, Mato Grosso do Sul, Brazil - \\ silvanascalon@ufgd.edu.br \\ ${ }^{3}$ Federal University of Grande Dourados, Faculty of Agrarian Sciences, Graduate program of Agronomy and Plant Production, Dourados, \\ Mato Grosso do Sul, Brazil - daiamugnol@hotmail.com sarinhaiibastos@hotmail.com paulinharissato@hotmail.com
}

Recebido para publicação: 06/06/2017 - Aceito para publicação: 01/02/2018

\begin{abstract}
The study was performed in the greenhouse of the Federal University of Grande Dourados (UFGD), from April to May, 2015. The aim of this study was to assess the effect of abscisic acid (ABA) different concentrations on Hymenaea courbaril L. seedlings water stress response and recovery after the rehydration. The following six treatments were evaluated: 1) Irrigation $0 \mu \mathrm{M} A B A ; 2)$ Irrigation $+10 \mu \mathrm{M} A B A$; 3) Irrigation $+100 \mu \mathrm{M} \mathrm{ABA}$; 4) Irrigation without $0 \mu \mathrm{M} A B A$; 5) Irrigation without $+10 \mu \mathrm{M} A B A$ and 6) Irrigation without $+100 \mu \mathrm{M}$ ABA. The irrigation without treatment was performed by withouting water until the photosynthetic rate was close to zero, after which the plants were rehydrated. The plants were then irrigated daily to maintain $70 \%$ of the water holding capacity of the soil for a 12-day recovery period. The ABA doses applied exogenously during the irrigation without period neither prevented the reduction of photosynthetic activity nor optimized the recovery of the gas exchanges and the carboxylation efficiency of Rubisco after water and seedling quality restoration. The $100 \mu \mathrm{M}$ ABA concentration promoted the degradation of chlorophylls independent of irrigation, showing that high concentrations of $\mathrm{ABA}$ may cause a residual effect on this species. The seedlings exhibited normal metabolic recovery after about 12 days of re-irrigation of the soil, which we attribute to species characteristics and not the tested treatments.

Key words: Ecophysiology, restoration, water condition
\end{abstract}

\section{Resumo}

Influência da aplicação exógena do ácido abscísico nas trocas gasosas de plântulas de Hymenaea courbaril L. (Fabaceae) submetidas ao déficit hídrico. O estudo foi realizado na casa de vegetação da Universidade Federal da Grande Dourados - UFGD, Dourados -MS, de abril a maio de 2015. O objetivo desse trabalho foi avaliar o efeito de diferentes concentrações de ácido abscísico (ABA) nas respostas ao estresse hídrico e na recuperação das mudas de Hymenaea courbaril L. após o reiirigação. Foram avaliados seis tratamentos sendo eles: 1) Irrigado sem ABA; 2) Irrigado + ABA $10 \mu \mathrm{M}$; 3) Irrigado + ABA $100 \mu \mathrm{M}$; 4) Sem irrigação e sem ABA; 5) Sem irrigação + ABA $10 \mu \mathrm{M}$; 6) Sem irrigação + ABA $100 \mu \mathrm{M}$. O tratamento sem irrigação consistiu na suspensão da irrigação até que a taxa fotossintética apresentasse níveis próximos de zero, quando as plantas foram reidratadas novamente com subsequente irrigação diária mantendo $70 \%$ da capacidade de retenção de água no solo, representando o período de restabelecimento, o qual durou 12 dias. As concentrações de $\mathrm{ABA}$ aplicadas exógenamente na época da suspensão da irrigação não evitaram a redução da atividade fotossintética e nem tão pouco otimizaram a recuperação das trocas gasosas e a eficiência de carboxilação da Rubisco após o restabelecimento normal de água e de qualidade das mudas. A concentração de $100 \mu \mathrm{M}$ de ABA promoveu degradação das clorofilas independente da condição hídrica, evidenciando que altas concentrações de ABA podem provocar efeito residual nesta espécie. As mudas apresentaram restabelecimento normal de seu metabolismo com a reirrigação do solo, o que ocorreu em torno de 12 dias, devido a características da espécie e não em função dos tratamentos testados.

Palavras-chave: Ecofisiologia, restabelecimento, condição hídrica 


\section{INTRODUCTION}

Hymenaea courbaril L. (Fabaceae) is an arboreal species with a wide geographical distribution and can be found in phytogeographical areas of the Amazon, Caatinga, Cerrado, Atlantic Forest, and Pantanal (LIMA; PINTO, 2016). This species has the ability to develop in different edaphoclimatic environments and is of forestry and environmental importance because of its potential as a carbon fixing and storage plant (CARVALHO, 2007).

The knowledge of the abiotic factors that affect natural regeneration or reforestation programs with native plants of the Cerrado are indispensable to the restoration of native vegetation. The growing concern about reforestation highlights the importance of studies on the tolerance or resistance of native species in both flooded and water deficit conditions, whereas the biome is characterized by seasonal rains and strong irradiance (LESSA et al., 2016).

Depending on the importance of water in the life cycle of plants, the deficit or excess of that element occupies a prominent position in studies on the environmental stresses. When exposed to water stress situations plants exhibit a wide range of molecular, cellular, physiological, and metabolic responses (FLOWERS, 2004) which can ensure their survival under such adverse conditions.

Plant responses to water deficit may include leaf area reduction, leaf abscission, stomatal closure, deep root growth, photosynthesis reduction, and increased leaf wax deposition (TAIZ et al., 2017). Many plants are able to delay dehydration by maintaining the hydration of their tissues through reduction of transpiration or increased water absorption; others tolerate dehydration due to their ability to keep their metabolism while dehydrated; other plants avoid drought by completing their cycle during the wet season, before the onset of drought (NASCIMENTO et al., 2011).

Plants under water stress typically exhibit greater accumulation of abscisic acid (ABA), which has been identified as a messenger in response pathways to perceived water stress and other environmental stresses and has several physiological effects on plant development. Some studies showed that application of ABA in intact plants could increase their tolerance to stress (YIN et al., 2004).

ABA is known as the stress hormone, triggering plant changes under water stress such as osmotic adjustment and stomatal closure upon increase in $\mathrm{CO}_{2}$ concentration or decrease in humidity (AASAMAA; SÕBER, 2011). The same authors used exogenous abscisic acid at $15-\mu \mathrm{M}$ concentration on fast, slow, and intermediate growing plants in order to assess its effect on different stomatal sensitivities. They found that ABA affected stomatal sensitivity - particularly the leaf water potential in plants subjected to water deficit and accelerated stomatal closure.

Based on several reports in the literature where ABA shows a "low persistence" in the plant, we postulated that the application of higher doses allows for a longer lasting effect. Thus, the aim of this study was to evaluate the effect of abscisic acid doses throughout the irrigation without period as well as in the water stress response and recovery of $H$. courbaril seedlings after the rehydration.

\section{MATERIAL AND METHODS}

The study was performed in the greenhouse of the Federal University of Grande Dourados (UFGD). Five month old $H$. courbaril (Herbarium of the Universidade Federal da Grande Dourados, $\mathrm{n}^{\circ}$ 3487) seedlings were transplanted into $5 \mathrm{~kg}$ capacity pots containing Carolina ${ }^{\circledR}$ substrate (having in its composition: vermiculite, charred rice husk, Canadian peat and fertilizer; $\mathrm{pH}$ : 5.65 ; total porosity: $76 \%)+$ soil $(1: 1)$, were acclimatized for 30 days with irrigation for a $70 \%$ water holding capacity, and were kept in the greenhouse under $40 \%$ shade being that these conditions were determined on the basis of pretesting). The plants were protected from rainfall by a plastic cover throughout the experiments.

The pots were divided into two groups, as follows: 1 - Control, where irrigation of the plants was periodically performed in order to maintain $70 \%$ of the water holding capacity of the soil and 2 - Treatment, where irrigation was withheld until photosynthetic rate was close to zero (Gomes et al. 2008), after which the plants were rehydrated and irrigated on a daily basis, maintaining $70 \%$ of the water holding capacity of the soil, for a 12-day recovery period (period in which the seedlings without irrigation presented values of photosynthesis similar the irrigated, after the rehydration).

Solutions of $0,10 \mu \mathrm{M}$, and $100 \mu \mathrm{M}$ abscisic acid were prepared and plants were pulverized to the drip point early in the morning. The plants of treatments 1 and 2 were or not sprayed with ABA. The application of ABA was held at the beginning of the experiment when the suspension of irrigation. 
At the beginning of the treatment (zero time) and every four days thereafter (days 4, 8, 12, 16, 20, 24, 28, 32, 36, and 40 after treatment start), the following assessment of gas exchanges was performed: the photosynthetic rate - $\mathrm{A}\left(\mu \mathrm{mol} \mathrm{m} \mathrm{m}^{-2} \mathrm{~s}^{-1}\right)$, foliar transpiration - $\mathrm{E}\left(\mathrm{mmol} \mathrm{m} \mathrm{m}^{-2}\right)$, stomatal conductance Gs $\left(\mathrm{mol} \mathrm{m} \mathrm{m}^{-2} \mathrm{~s}^{-1}\right)$ and internal $\mathrm{CO}_{2}$ concentration - $\mathrm{Ci}\left(\mu \mathrm{mol} \mathrm{mol}{ }^{-1}\right)$ were measured using an infrared gas analyzer (IRGA) (Model LCi PRO; Analytical Development Co. Ltd., Hoddesdon, UK). From the gas exchange data, the following ratios were calculated: instantaneous water-use efficiency (WUE $\mu$ mol $\mathrm{CO}_{2} / \mathrm{mmol}^{-1} \mathrm{H}_{2} \mathrm{O}$ ), intrinsic water-use efficiency (IWUE $\mu \mathrm{mol} \quad \mathrm{CO}_{2} / \mathrm{mmol}^{-1} \quad \mathrm{H}_{2} \mathrm{O}$ ), and instantaneous carboxylation efficiency (A/Ci $\mu$ mol m $\left.{ }^{-2} \mathrm{~s}^{-1} / \mu \mathrm{mol} \mathrm{mol}^{-1}\right)$.

Every gas exchange evaluation was performed in two pairs of visually healthy and fully expanded leaves in two individuals from each treatment batch until the photosynthetic values approached zero. The gas exchange measurements were carried out on clear days without clouds, from 9 to $10 \mathrm{am}$, in order for the gas exchange to coincide with the period of maximum photosynthesis.

The quantum efficiency of the photosystem II (Fv/Fm) and the efficiency of the effective photosystem on the absorbed energy conversion (Fv/F0) were analyzed with a portable fluorometer (model OS30p) (Opti-Sciences Chlorophyll Fluorometer, Hudson, USA). The fluorescence determination was carried out between 8 and $11 \mathrm{am}$ on the same leaves used for gas exchanges evaluation. The leaves were subjected to 30 minutes of dark adaptation using adapter clips, so that all reaction centers in the leaf were "open," that is, the electron transport photosynthetic system was completely oxidized.

Chlorophyll index (SPAD) was determined using a SPAD Konica-Minolta 502 chlorophyll meter. Growth was analyzed using height, stem diameter, and shoot and root biomass (BENINCASA, 2003). The Dickson Quality Index was then calculated according to the equation DQI = [total dry weight/(height/diameter ratio + shoot dry weight ratio/root dry weight)] (DICKSON et al., 1960).

The gas exchanges assessment was completely randomized and contained the following six treatments: 1) Irrigation $0 \mu \mathrm{M} A B A$; 2) Irrigation $+10 \mu \mathrm{M} A B A$; 3) Irrigation $+100 \mu \mathrm{M} A B A$; 4) irrigation without $0 \mu \mathrm{M}$ $\mathrm{ABA}$; 5) irrigation without $+10 \mu \mathrm{M} \mathrm{ABA}$ and 6) irrigation without $+100 \mu \mathrm{M} \mathrm{ABA}$. Each treatment was performed with 5 repetitions, each repetition corresponding to a new seedling. Analysis of variance was performed and the means of each treatment were submitted to the $t$ test at $5 \%$ probability when statistical effects were found.

A completely randomized design in a 6 treatments $\times 3$ evaluation periods factorial was used for the other evaluations, with 5 repetitions, where each repetition corresponded to a seedling. Analysis of variance (ANOVA, $\mathrm{p}<0.05$ ) was performed and the means were compared by the Scott-Knott test $(\mathrm{p}<0.05)$ using the statistical program SISVAR (FERREIRA, 2011).

\section{RESULTS}

The water deficit caused by irrigation without influenced some physiological parameters of the $H$. courbaril seedlings. The seedlings under water deficit, with or without ABA, exhibited significant variations in their photosynthetic rates. The onset of photosynthetic rate decreases occurred at the $20^{\text {th }}$ day with a subsequent intensification until the $28^{\text {th }}$ day, when the rates approached zero. After re-irrigation, seedlings recovered their photosynthetic metabolism in 12 days, demonstrating higher levels than those of irrigated seedlings without irrigation without (Figure 1A). These results suggest that the species possesses adaptation mechanisms after a 28-day water deficit period.

The transpiration rate (Figure 1B) for seedlings under water deficit was followed by reductions in stomatal conductance (Figure 1C), which is considered one of the first responses to drought because it prevents dehydration of plant tissues.

Seedlings submitted to water deficit without $\mathrm{ABA}$ and with $10 \mu \mathrm{M}$ ABA showed a significant drop in internal $\mathrm{CO}_{2}$ concentration $(\mathrm{Ci})$ starting at the $24^{\text {th }}$ day of irrigation without. However, seedlings without irrigation $+100 \mu \mathrm{M}$ ABA did not differ statistically from seedlings with constant irrigation with or without ABA (Figure 1D). 

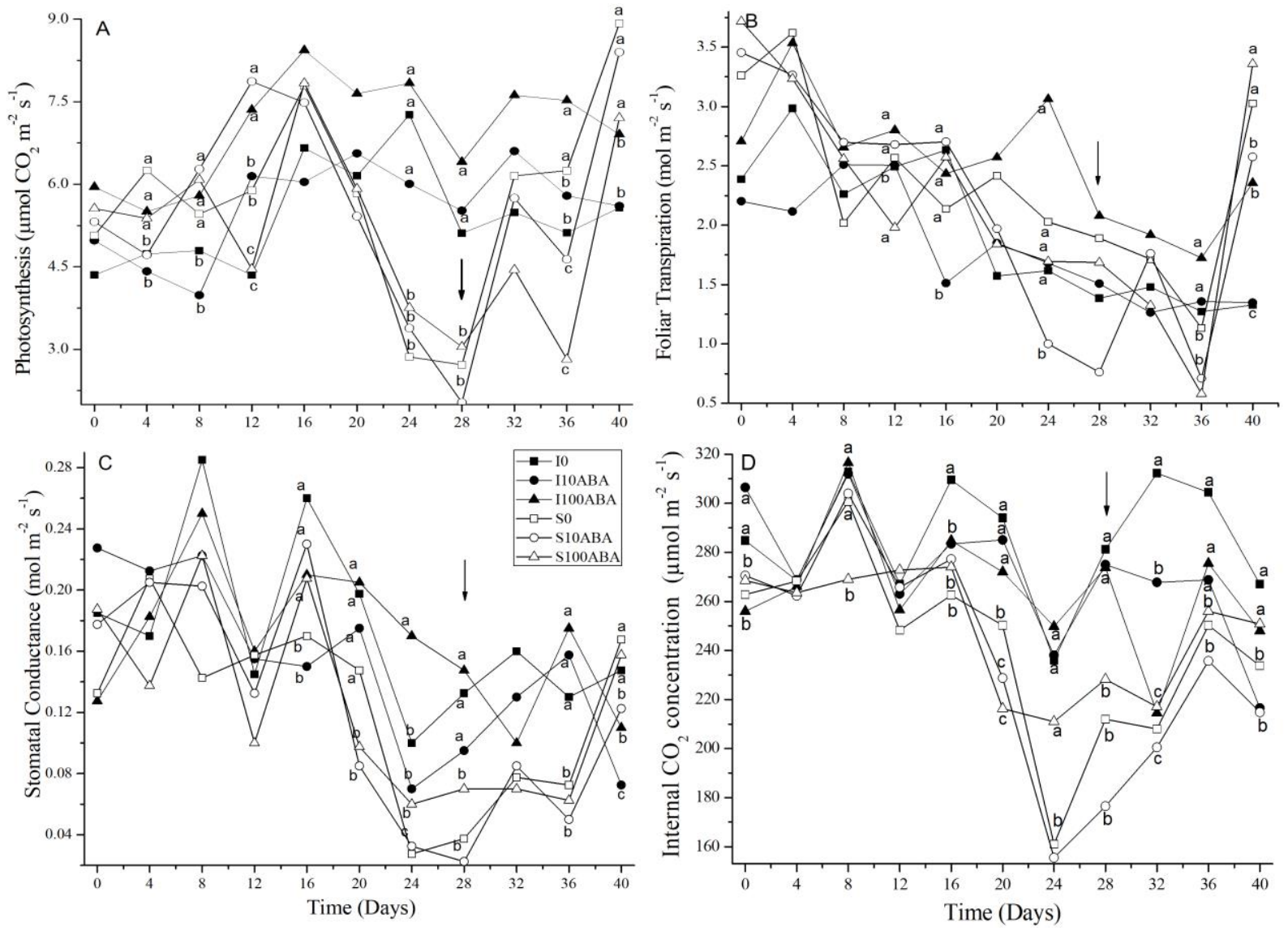

Figure 1. Photosynthesis (a), transpiration (b), Stomatal conductance (c) e Internal $\mathrm{CO}_{2}$ concentration (d) seedlings of Hymenaea courbaril $\mathrm{L}$ submitted to exogenous application of $\mathrm{ABA}(0,10,100 \mu \mathrm{M})$ and water deficit ( $\mathrm{I}=$ irrigation; $\mathrm{S}=$ Irrigation without). Media followed the same letter do not differ. Arrows indicate irrigation ( $28^{\text {th }}$ day of the experiment).

Figura 1. Fotossíntese (a), transpiração (b), condutância estomática (c) e concentração interna de $\mathrm{CO}_{2}$ (d) em plantas de Hymenaea courbaril L submetidas à aplicação exógena de $\mathrm{ABA}(0,10,100 \mu \mathrm{M}) \mathrm{e}$ deficiência hídrica ( $\mathrm{I}=$ irrigação; $\mathrm{S}=$ sem irrigação). Média seguida pela mesma letra não diferem. Setas indicam irrigação ( $28^{\circ}$ dia do experimento).

After restoration of irrigation, a recovery in $\mathrm{Ci}$ values was observed, being most significant in seedlings subjected to water deficit $+100 \mu \mathrm{M}$ ABA treatment. This elevation in the $\mathrm{Ci}$ values for treatments involving water deficit related to increases in photosynthetic rate (Figure 1A).

Carboxylation efficiency fluctuated throughout the evaluation period, but a significant reduction was observed at the $28^{\text {th }}$ day in the treatments involving water deficit and ABA application. After 12 days of soil reirrigation, the treatments did not vary statistically among them, except for the treatment involving water deficit without ABA (Figure 2A). A reduction in water use efficiency (WUE) (Figure 2B) was observed in treatments with water deficit 12 days after the restoration of irrigation, although these same treatments subsequently exhibited a transpiration enhancement (Figure 1D). 


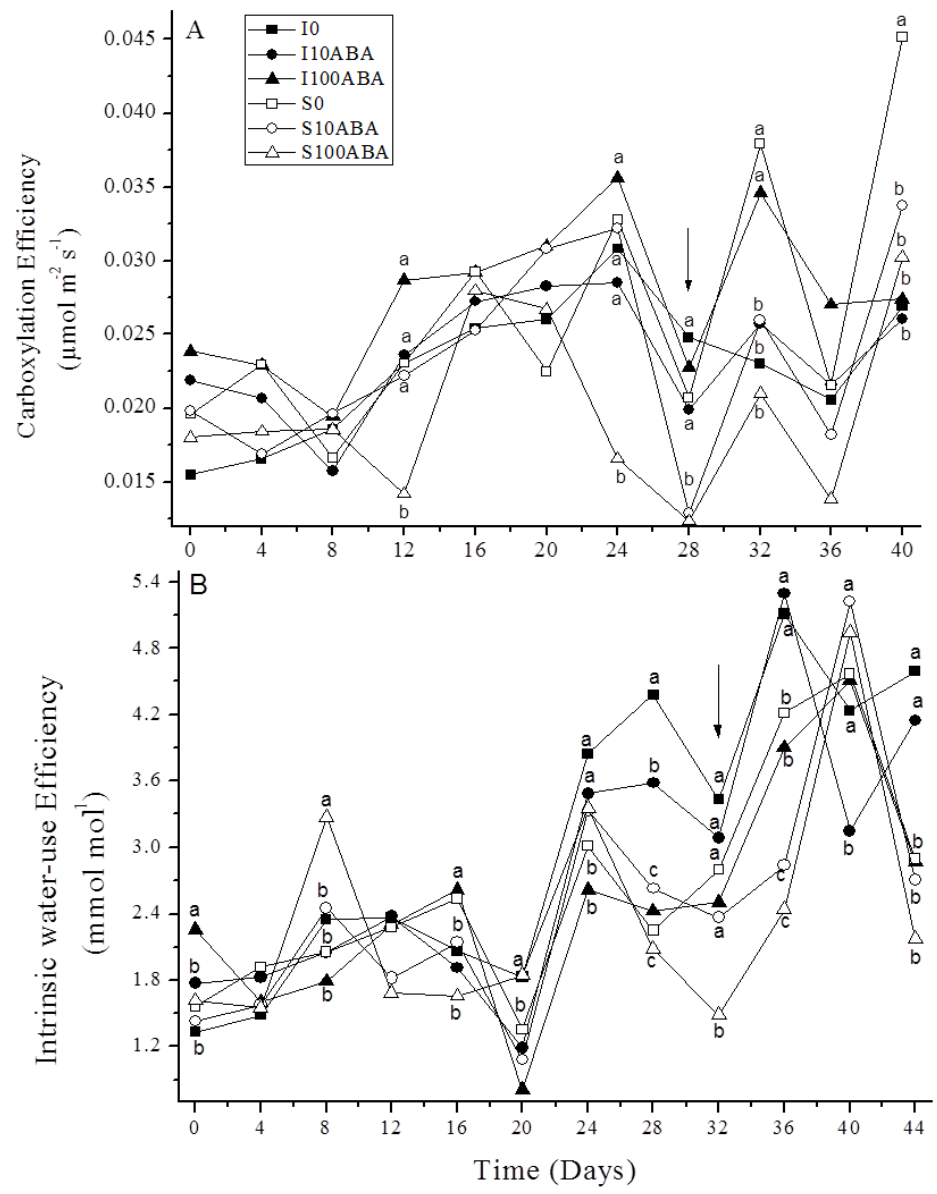

Figure 2. Carboxylation efficiency (a) e Intrinsic water-use efficiency (b) in seedlings of Hymenaea courbaril L submitted to exogenous application of $\mathrm{ABA}(0,10,100 \mu \mathrm{M})$ and water deficit $(\mathrm{I}=$ irrigation; $\mathrm{S}=$ Irrigation without). Media followed the same letter do not differ. Arrows indicate irrigation ( $28^{\text {th }}$ day of the experiment).

Figura 2. Eficiência carboxilativa (a) e Eficiência intrínseca no uso da água (b) em plantas de Hymenaea courbaril L submetidas à aplicação exógena de $\mathrm{ABA}(0,10,100 \mu \mathrm{M})$ e deficiência hídrica (I= irrigação; $\mathrm{S}=$ sem irrigação). Media seguida pela mesma letra não diferem. Setas indicam irrigação ( $28^{\circ}$ dia do experimento).

A significant reduction in effective efficiency of conversion of energy absorbed by the photosystem (Fv/F0) was observed in the irrigation without $+10 \mu \mathrm{M}$ ABA treatment (Figure 3A).

The seedlings subjected to irrigation without exhibited a reduction in quantum efficiency of the photosystem II (Fv/Fm) (Figure 3B) when the photosynthetic rates reached zero. 

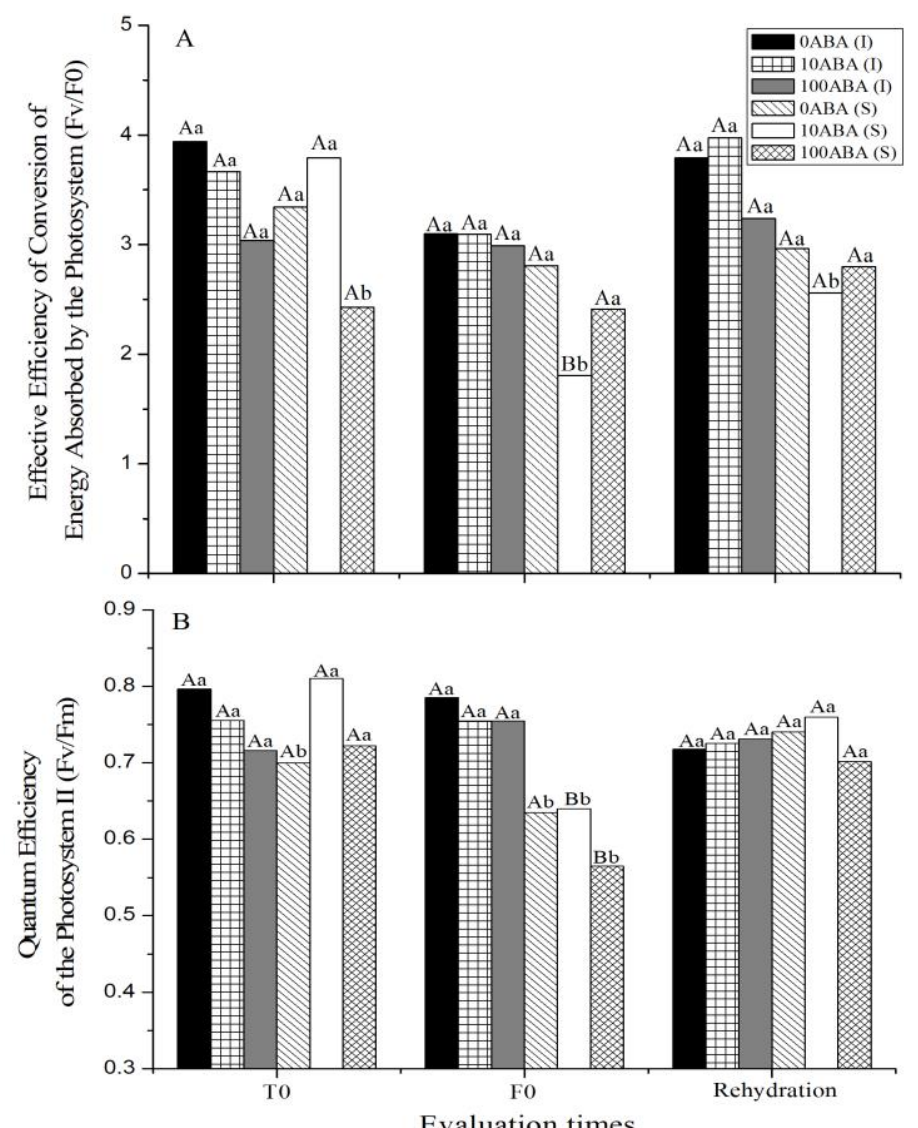

Figure 3. Fv/F0 (a) and Fv/Fm (b) in seedlings of Hymenaea courbaril L submitted to exogenous application of $\mathrm{ABA}(0,10,100 \mu \mathrm{M})$ and water deficit $(\mathrm{I}=$ irrigation; $\mathrm{S}=$ Irrigation without). Media followed the same letter do not differ. It is the beginning of the experiment (T0), photosynthesis zero (F0) and rehydration of soil. Uppercase compare between periods and lower-case letters compare treatments at the same time.

Figura 3. Fv/F0 (a) e Fv/Fm (b) em plantas de Hymenaea courbaril L submetidas à aplicação exógena de ABA $(0,10,100 \mu \mathrm{M})$ e deficiência hídrica (I= irrigação; $\mathrm{S}=$ sem irrigação). Sendo o início do experimento (T0), fotossíntese zero (F0) e reidratação do solo. Letras maiúsculas comparam entre os períodos e letras minúsculas comparam os tratamentos no mesmo tempo.

Lower chlorophyll index values (Figure 4A) were observed for plants treated with $100 \mu \mathrm{M} \mathrm{ABA}$, independent of water availability and the DQI (Figure 4B) did not differ significantly among the different treatments throughout the experimental period. These results show that the water deficit did not affect the quality of the seedlings of this species during the period of study. 

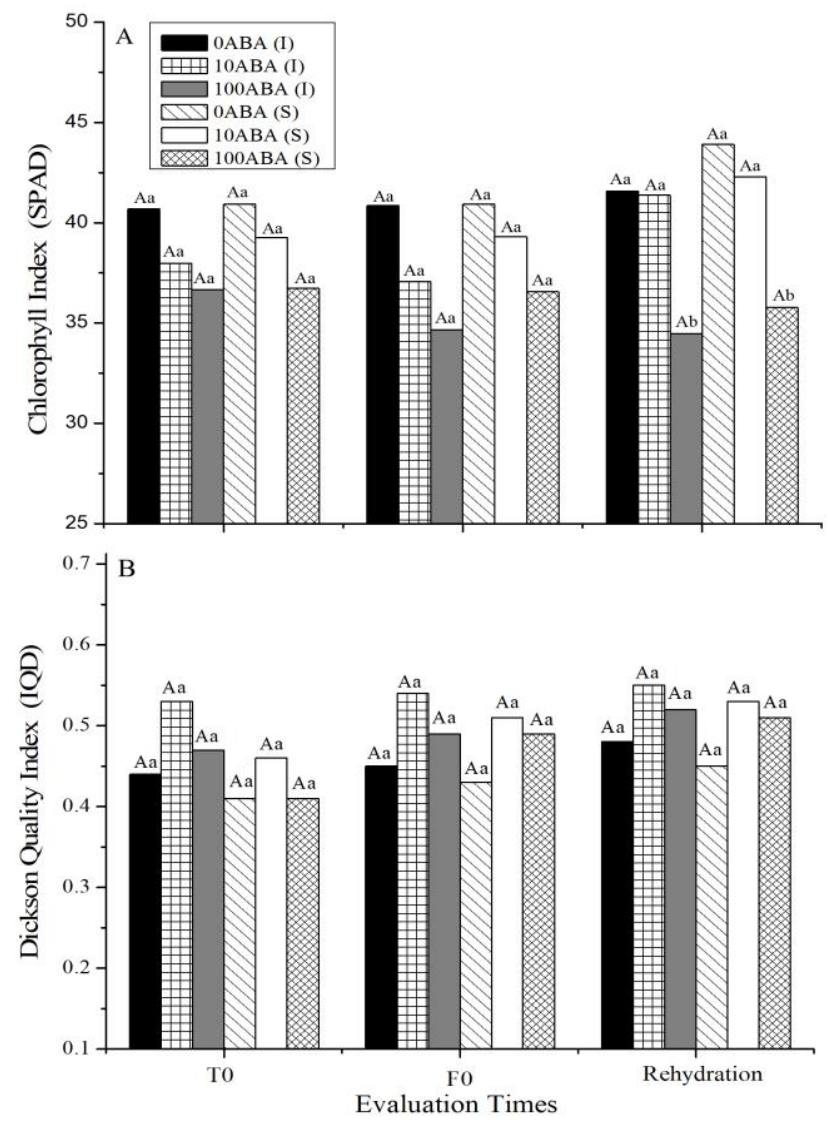

Figure 4. Chlorophyll Index (a) and Dickson Quality Index (b) in seedlings of Hymenaea courbaril L. submitted to exogenous application of $\operatorname{ABA}(0,10,100 \mu \mathrm{M})$ and water deficit (I= irrigation; $\mathrm{S}=$ Irrigation without). It is the beginning of the experiment (T0), photosynthesis zero (F0) and and rehydration of soil. Uppercase compare between periods and lower-case letters compare treatments at the same time.

Figura 4. Índice de clorofila (a) e Índice de Qualidade de Dickson (b) em plantas de Hymenaea courbaril L submetidas à aplicação exógena de $\mathrm{ABA}(0,10,100 \mu \mathrm{M})$ e deficiência hídrica (I= irrigação; $\mathrm{S}=$ sem irrigação). Sendo o início do experimento (T0), fotossíntese zero (F0) e restabelecimento da irrigação do solo. Letras maiúsculas comparam entre os períodos e letras minúsculas comparam os tratamentos no mesmo tempo.

\section{DISCUSSION}

The reduction of intercellular $\mathrm{CO}_{2}$ concentration is related with stomatal closure, caused either by dehydration of the guard cells or by hormonal response (FILHO et al., 2008). Reduction of the photosynthetic rate in plants subjected to water deficit conditions is associated with stomatal closure, induced by changes in leaf water status (SILVA et al., 2009), as well as the reduction in stomatal conductance may represent a vantage immediate prevent dehydration of plant tissues (EGEA et al., 2011).

The same behavior was observed in Guazuma ulmifolia Lam. seedlings assessed at different field capacities $(100 \%, 50 \%, 25 \%$, and $12.5 \%)$. Seedlings grown under lower water availability exhibited reduced stomatal conductance, photosynthesis, and transpiration as lower soil water content contributed to partial stomatal closure, and therefore, to a reduction in stomatal conductance (SCALON et al., 2011). The authors reported that this behavior caused reduced transpiration, $\mathrm{CO}_{2}$ assimilation, and photoassimilate production. Similar results were also observed in seedlings Copaifera langsdorffii Desf. cultivated in four different water retention capacities (WRC - 25\%, 50\%, 75\% and 100\%), so that the WRC of 25\% impaired absorption of water,

FLORESTA, Curitiba, PR, v. 48, n. 2, p. 163 - 172, abr / jun 2018

Freitas. V. M. B. et.al.

ISSN eletrônico 1982-4688

DOI: $10.5380 /$ rf.v48 i2.53076 
which consequently affected the photosynthetic process suggesting that the seedlings have undergone a water deficit (ROSA et al., 2017).

Similar results were observed in Calendula officinalis plants subjected to water deficit and treated with ABA doses, where the $100-\mu \mathrm{M}$ dose did not increase the water stress tolerance of the species (PACHECO et al., 2011).

Most of the water absorbed by roots evaporates from leaf surfaces by transpiration, while a small part remains in the plant meeting growth, photosynthetic, and other metabolic demands. The WUE of certain species reflects their ability to fix carbon through transpiration

Moreover, after water restoration the seedlings did not reach the same values of the irrigated treatments. Because $\mathrm{Fv} / \mathrm{F} 0$ is an indicator of the electron transport chain status and its effectiveness, this decrease indicates possible damage on the electron transport chain. Although it contains information similar to the reason $\mathrm{Fv} / \mathrm{Fm}$, this right extends small variations detected (AZEVEDO et al., 2011).

The reason $\mathrm{Fv} / \mathrm{Fm}$ is an estimate of the quantum efficiency of photochemical activity of PSII in maximum, when all reaction centers are open (BAKER, 2008). This relationship has been widely used to detect disturbances in photosynthetic system caused by stress, characterized as a strong fluorescence study parameter of the chlorophyll- $a$, since your decrease indicates a decline in the efficiency of PSII in photochemistry, suggesting damage or disturbance in the photosynthetic apparatus (SCHANSKER et al., 2011).

In this study, only the treatments with irrigation without showed Fv/Fm ratios below the ideal values when the photosynthetic rates were close to zero. However, when the soil irrigation was restored, the values increased again, and no statistical difference was observed relative to the treatments without irrigation without.

This is owing to the fact that in some species, application of ABA can promote the production of ethylene (KERBAUY, 2008), a hormone involved in chlorophyll degradation (TAIZ et al., 2017). The determination of the leaf chlorophyll content is important because it permits inferences about a plant's photosynthetic capacity (CARVALHO et al., 2015).

Hunt (1990) suggested that seedlings of satisfactory planting quality have a DQI of 0.2 . In our study, the seedlings in all treatments exhibited DQIs above the recommended values, reinforcing the idea that despite a reduction in photosynthetic activity, stress did not damage the quality of the seedlings.

Thus, it is expected that the Cerrado plants acquire, over the generations, gene that allows heritage to respond efficiently to a number of limiting factors, whereas this environment naturally has policies that require high plants stomatal and photochemistry efficiency even in low water availability (RUGGIERO et al., 2006).

\section{CONCLUSION}

The analyses carried out lead to the conclusion that:

- The ABA applied exogenous at the time of the suspension of irrigation not avoided reducing the photosynthetic activity and neither optimized recovery of gas exchange and improvement of carboxylation of Rubisco after restoring normal water and quality of seedlings.

- The concentration $100 \mu \mathrm{M}$ promoted degradation of chlorophylls water condition independent, showing that high concentrations of ABA can cause residual effect on this species.

- The seedlings showed normal your metabolism is restored with the re-irrigation of the soil, which occurred around 12 days due to characteristics of the species and not on the basis of the treatments tested.

\section{REFERENCES}

AASAMAA, K.; SÕBER, A. Stomatal sensitivities to changes in leaf water potential, air humidity, $\mathrm{CO}_{2}$ concentration and light intensity, and the effect of abscisic acid on the sensitivities in six temperate deciduous tree species. Environmental and Experimental Botany, Oxford, v. 71, p. 72-78, 2011.

AZEVEDO, N. A. D.; PEREIRA, P. P. A.; COSTA D. P.; SANTOS, A. C. C. Fluorescência da clorofila como uma ferramenta possível para seleção de tolerância à salinidade em girassol. Revista Ciência Agronômica, Ceará, v. 42, n. 4, p. 893-897, 2011.

BAKER, B. Chlorophyll Fluorescence: A probe of photosynthesis in vivo. Annual Review of Plant Biology, California, v. 59, p. 89-113, 2008.

BENINCASA, M. M. P. Análise de crescimento de plantas: noções básicas. Jaboticabal: FUNEP, 2003. 41p.

CARVALHO, P. E. R. Jatobá - do - Cerrado Hymenaea stigonocarpa. Embrapa Florestas (Embrapa Florestas, Colombo. Circular Técnica 133), p. 2, 2007. 
CARVAlHO, R. P.; DAVIDE, L. M. C.; BORGES, F. L. G.; DAVIDE, A. C.; DANIEL, O. Respostas morfofisiológicas entre procedências de canafístula submetidas a diferentes condições hídricas e nutricionais. Pesquisa Florestal Brasileira, Colombo, v. 35, n. 83, p. 179-188, 2015.

DICKSON, A.; LEAF, A. L.; HOSNER, J. F. Quality appraisal of white spruce and white pine seedling stock in nurseries. Forest Chronicle, Canadá, v. 36, p. 10-13, 1960.

EGEA, G.; VERHOEF, A.; VIDALE, P. L. Towards na improved and more flexible representation of water stress in coupled photosynthesis-stomatal conductance models. Agricultural and Forest Meteorology, USA, v. 151, n. 10, p. 1370-1384, 2011.

FERREIRA, D. F. SISVAR: A computer statistical analysis system. Ciência e Agrotecnologia, Lavras, v. 35, n. 6, p. 1039-1042, 2011.

FILHO, J. R.; AMARAL, L. R.; MACHADO, D. F. S. P.; MEDINA, C. L.; MACHADO, E. C. Deficiência hídrica, trocas gasosas e crescimento de raízes em laranjeira 'Valencia' sobre dois tipos de porta enxerto. Bragantia, Campinas, v. 67, n. 1, p. 75-82, 2008.

FLOWERS, T. J. Improving crop salt tolerance. Journal of Experimental Botany, Oxford, v. 35, p. 307-319, 2004.

GOMES, F. P.; OliVA, M. A.; MIElKe, M. S.; AlMEIDA, A-A. F.; LEITE, H. G.; AQUINO, L. A. Photosynthetic limitations in leaves of young Brazilian Green Dwarf coconut (Cocos nucifera L.'nana') palm under well-watered conditions or recovering from drought stress. Environmental and Experimental Botany, Oxford, v. 62, p. 195-204, 2008.

HUNT, G. A. Effect of styroblock design and cooper treatment on morphology of conifer seedlings. In: Proceedings of Target Seedling Symposium, Meeting of the Western Forest Nursery Associations; Roseburg. Fort Collins: USDA Forest Service p. 218-222, 1990.

KERBAUY G. B. Fisiologia vegetal. 2.ed. Rio de Janeiro: Guanabara p.271-295, 2008.

LESSA, J. H. L.; ARAÚJO, A. M.; SILVA, G. N. T.; GUlHERME, L. R. G.; LOPES, G. Adsorption, desorption reactions of selenium (VI) in tropical cultivated and uncultivated soils under Cerrado biome. Chemosphere, Oxford, v.164, p.271-277, 2016.

LIMA, H. C.; PINTO, R. B. Hymenaea in Lista de Espécies da Flora do Brasil. Jardim Botânico do Rio de Janeiro. Disponível em: <http://floradobrasil.jbrj.gov.br/jabot/floradobrasil/FB83197>. Acesso em: 25 Mar. 2016.

NASCIMENTO, H. H. C.; NOGUEIRA, R. J. M. C.; SILVA, E. C.; SILVA, M. A. Análise do crescimento de mudas de jatobá (Hymenaea courbaril L.) em diferentes níveis de água no solo. Revista Árvore, Viçosa, v. 35, n. 3, p. 617-626, 2011.

PACHECO, A. C.; CAMARGO, P. P.; SOUZA, G. M. Deficiência hídrica e aplicação de ABA nas trocas gasosas e no acúmulo de flavonoides em calêndula (Calendula officinalis L.). Acta Scientiarum Agronomy, Maringá, v. 33, n. 2, p. 275-281, 2011.

ROSA, D. C. J.; SCALON, S. P. Q.; CREMON, T.; CECCON, F.; DRESCH, D. M. Gas exchange and antioxidant activity in seedlings of Copaifera langsdorffii Desf. under different water conditions. Anais da Academia Brasileira de Ciências, Rio de Janeiro, v. 89, n. 4, p. 3039-3050, 2017.

RUGGiero, P. G. C.; PIVEllo, V. R.; SPAROVEK, G.; TERAMOTO, E.; PIRES NETO, A. G. Relação entre solo, vegetação, e topografia em área de cerrado (Parque Estadual de Vassununga, SP): como se expressa em mapeamentos. Acta Botanica Brasilica, Viçosa, v. 20, n. 2, p. 383-394, 2006.

SCALON, S. P. Q.; MUSSURY, R. M.; EUZÉBIO, V. L. M.; KODAMA, F. M.; KISSMAN, C. Estress hídrico no metabolismo e crescimento inicial de mudas de mutamo (Guazuma ulmifolia Lam.). Ciência Florestal, Santa Maria, v. 21, n. 4, p. 655-662, 2011.

SCHANSKER, G.; TÓTH, S. Z.; KOVÁCS, L.; HOLZWARTH, A. R.; GARAB, G. Evidence for a fluorescence yield change driven by a light-induced conformational change within photosystem II during the fast

FLORESTA, Curitiba, PR, v. 48, n. 2, p. 163 - 172, abr / jun 2018

Freitas. V. M. B. et.al.

ISSN eletrônico 1982-4688

DOI: $10.5380 /$ rf.v48 i2.53076 
chlorophyll a fluorescence rise. Biochimica et Biophysica Acta (BBA)-Bioenergetics, Germany, v. 1807, n. 9, p. 1032-1043, 2011.

SILVA, E. C.; NOGUEIRA, R. J. M. C.; VALE, F. H. A.; ARAÚJO, F. P.; PIMENTA, M. A. Stomatal changes induced by intermittent drought in four umbu tree genotypes. Brazilian Journal of Plant Physiology, Campinas, v. 21, n. 1, p. 33-42, 2009.

TAIZ, L; ZEIGER, E.; MOLLER, I. M.; MURPHY, A. Fisiologia e desenvolvimento vegetal. [tradução: Alexandra Antunes Mastroberti et al.] ; revisão técnica: Paulo Luiz de Oliveira. - 6 a . ed. - Porto Alegre : Editora Artmed, 2017. 858p.

YIN, C.; DUAN, B.; WANG, X.; LI, C. Morphological and physiological responses of two contrasting Poplar species to drought stress and exogenous abscisic acid application. Plant Science, New York v. 167, n. 5, p. 1091-1097, 2004. 